\title{
China Fuels its Future with Africa's Riches
}

\author{
Sanusha Naidu and Martyn Davies ${ }^{1}$
}

China is playing an increasingly influential role on the continent of Africa, and there is concern that the Chinese intend to aid and abet African dictators, gain a stranglehold on precious African natural resources, and undo much of the progress that has been made on democracy and governance in the last 15 years in African nations.

Christopher Smith, US House of International

Relations Committee, July 2005

Investing in African extractive industries is a risky business, but China is desperately in need of raw materials to feed its booming economy, hence the government is willing to shoulder most of the risk for Chinese companies looking to invest in Africa.

M Sorbara, The Nation newspaper, Kenya, 14 April 2006

\section{Introduction}

China's Africa relations have become the subject of much speculation and controversy in recent years. Much of the debate has been about the fact that Sino-African relations bring into focus, particularly for the industrialised powers, the emergence of a competitor for the continent's vast natural resources.

Fuelled by the growing dynamism of the Chinese economy, which has averaged $9 \%$ growth per annum over the past two decades, [and] nearly tripled the country's GDP, ${ }^{2}$ Beijing's engagement with African governments must be seen through the prism of the need to secure access to oil and natural resources to sustain its economic boom. As much as China's thrust into Africa may be seen as one sided, Beijing's commodity hunger has, nevertheless, opened up new opportunities for resource-rich countries on the continent. 
A special report by Deutsche Bank produced in 2006 says China will remain hungry for commodities over the next 15 years, while their forecast model for China's import demand until 2020 shows that 'demand growth rates will remain in lower double digit territory over the next decade for most commodities'. ${ }^{3}$ This is significant for African countries as the commodity windfall could be used to diversify economies into manufacturing and services. ${ }^{4}$ However, there are some reservations about China's interest in Africa's natural resource sector. Critics from both the continent and elsewhere have been quick to point out that China's commodity safari is exploitative in that it is purely extractive, benefiting only a small cluster of countries which remain vulnerable to the onslaught of the 'Dutch Disease' (a phenomenon in which the revenues of natural resource extraction have an unintended corrosive effect on the political economy of the exporting country). Moreover, it is their contention that China's foray into the continent is as much political as it is economic. This is aptly reflected by Eisenman and Kurlantzick who note that Africa is central to Beijing's global strategy. 'China's growing industries demand new energy and raw material suppliers; its exporters want markets; its diplomats require support in international organisations; and its propaganda still seeks support from allies to advance Chinese interests and, when necessary, to counter the United States. ${ }^{5}$ On the other hand, proponents of China's Africa policy argue that in so far as this may be true, what sets China's thirst for natural resources apart from the 19th century scramble for Africa is the fact that now, the economic engagement is accompanied by investment in and upgrading of infrastructure and transport facilities, which are central to Africa's development trajectory.

In short, there are mixed reactions to China's economic relations with Africa, especially with regard to what motivates this engagement and the implications thereof for governance reform and sustainable development in African countries. Recently it has emerged that China's acquisition of significant assets in Africa and elsewhere has become part of Beijing's key strategy to disengage from global market pricing mechanisms and to develop an alternative mechanism. In light of these points, the main thrust of this article is to examine critically China's acquisition of and investment in Africa's natural resource sector and the short- to medium-term political, economic, social, and environmental implications this has for African states.

\section{Putting the commodity surge into context}

According to the above-mentioned Deutsche Bank report, Chinese 
commodity imports have surged by a factor of 20 over the past two decades to nearly $\$ 200$ billion by $2004 .^{6}$ As Table 1 illustrates, crude oil, chemical elements and compounds, and plastic materials top the list of China's commodity imports and 'together these commodities account for roughly $40 \%$ of commodity imports and $15 \%$ of total imports', the report says. With respect to the other commodities reflected in the table, China has probably become the world's leading importer of plastic materials, metal ores, oil seeds, textile fibres and pulp and paper.

The commodity surge looks set to continue. Projections noted in Table 2 (next page) suggest that the import demand for commodities

\begin{tabular}{|l|c|c|c|c|}
\hline \multicolumn{5}{|c|}{ Table 1: China's top 10 import commodities in 2004* } \\
\hline Commodity & $\begin{array}{c}\text { Value } \\
\text { (US\$ bn) }\end{array}$ & $\begin{array}{c}\text { Global } \\
\text { rank }\end{array}$ & $\begin{array}{c}\text { Share in } \\
\text { world imports } \\
\text { (\%) }\end{array}$ & $\begin{array}{c}\text { Share in } \\
\text { total Chinese } \\
\text { imports } \\
\text { (\%) }\end{array}$ \\
\hline Crude petroleum & 33.9 & 3 & 6.1 & 6.0 \\
\hline $\begin{array}{l}\text { Chemical elements } \\
\text { and compounds }\end{array}$ & 27.7 & 2 & 9.5 & 4.9 \\
\hline Plastic materials, etc. & 25.3 & 1 & 12.9 & 4.5 \\
\hline Iron and steel & 23.2 & 2 & 9.0 & 4.1 \\
\hline $\begin{array}{l}\text { Metalliferous ores } \\
\text { and metal scrap }\end{array}$ & 23.1 & 1 & 21.7 & 4.1 \\
\hline Non-ferrous metals & 14.3 & 3 & 8.5 & 2.6 \\
\hline $\begin{array}{l}\text { Oil seeds, oil nuts } \\
\text { and oil kernels }\end{array}$ & 7.2 & 1 & 27.8 & 1.3 \\
\hline $\begin{array}{l}\text { Textile fibres, not } \\
\text { manufactured, and waste }\end{array}$ & 6.7 & 1 & 23.9 & 0.9 \\
\hline $\begin{array}{l}\text { Chemical materials } \\
\text { and products }\end{array}$ & 5.6 & 4 & 6.0 & 19.2 \\
\hline Pulp and paper & 5.3 & 1 & & \\
\hline Source: UN Comtrade database in Deutsche Bank Research Report & \\
\hline Sorted by import value; values are for gross imports; two digit SITC-1 classification \\
\hline
\end{tabular}




\begin{tabular}{|l|l|c|c|c|c|}
\hline \multicolumn{5}{|c|}{ Table 2: Projections for China's commodity import demand } \\
\hline & & \multicolumn{2}{c|}{ Annual Demand } & 2006-2020, \% change \\
\hline Commodity & Unit & Latest & $\mathbf{2 0 2 0}$ & Total & Avg. p.a. \\
\hline Iron ore & m tonnes & 148 & 710 & 380 & 10 \\
\hline Oil & m tonnes & 91 & 1860 & 1940 & 20 \\
\hline Soy & m tonnes & 26 & 50 & 80 & 4 \\
\hline Coal & m tonnes & 11 & 810 & 7400 & 20 \\
\hline Copper & m tonnes & 3 & 20 & 600 & 10 \\
\hline Manganese & m tonnes & 3 & 13 & 360 & 10 \\
\hline Meat & m tonnes & 0.3 & 4 & 1260 & 20 \\
\hline Wood & $\begin{array}{l}\text { m cubic } \\
\text { meters }\end{array}$ & 34 & 150 & 330 & 10 \\
\hline Source: Deutsche Bank Research & & & & \\
\hline
\end{tabular}

such as iron ore, manganese, wood, and meat will, by 2020, remain in lower double-digit figures and, when translated in absolute terms, this demand will represent substantial increases in imports. ${ }^{8}$ Such trends are fuelled by what analysts assert are patterns linked to China's future developmental path and the relationship between the country's GDP per capita and its demand per capita for certain commodities.

If these predictions are accurate and follow the linear trend of industrial development of other Asian countries such as South Korea, China's commodity surge will, indeed, continue. At present, China's demand for these commodities is underpinned by the booming domestic economy and the demands this is creating for overseas exploration. There are also strategic issues relating to China's coalpowered energy needs.

While China's outward expansion has been intrinsically linked to its growing energy needs, in terms of other commodities such as copper, iron ore, manganese, steel, chromium, lead, and wood, China's demand is undoubtedly aligned to booming industries at home. For instance, the increased demand for copper is linked to China's diversification into the information technology, automotive and construction sectors. ${ }^{9}$ Similarly, steel production is a rapidly 
growing industry in China and hence demand for this and other such metals is unlikely to diminish.

\section{Africa's natural resources: China's new Silk Road}

The contemporary shifts in the global economic system are linked to the political economy of the current global demand for energy. With volatility in the Middle East threatening the global supply of oil, and with it China's demand for sustainable long-term access to crude oil, the Asian giant is turning to 'another major oil producer whose risks and challenges have caused it to be overlooked by much of the rest of the world - Africa'. ${ }^{10}$

Global energy demands have made Africa an increasingly important player. The continent currently contributes $12 \%$ of the world's liquid hydrocarbon production, and one in four barrels of oil discovered outside the US and Canada between 2000 and 2004 came from Africa, ${ }^{11}$ according to Adam Wolfe writing in the Power and Interest News Report.

Wolfe notes that West African oil is attractive because of its lowsulphur content, which makes it highly desirable for environmental purposes, and it can readily be transported to the eastern US seaboard and easily processed by Chinese refineries. Furthermore, IHS Energy calculates that by 2010, Africa will supply raw materials for $30 \%$ of the world's hydrocarbon production. ${ }^{12}$ It therefore comes as no surprise that Africa has become the commercial playground for competing interests from both the continent's traditional development partners and the rising powers of India and China.

In January 2006, the Chinese government released its African policy as a White Paper. While the White Paper set out the principles governing China's overall diplomatic and economic relationship with Africa, it also identified resource co-operation as one of the cornerstones of Beijing's engagement with the continent.

The Chinese government encourages and supports competent Chinese enterprises to co-operate with African nations in various ways on the basis of the principle of mutual benefit and common development, to develop and exploit rationally their resources, with a view to helping African countries to translate their advantages in resources to competitive strength, and realise sustainable development in their own countries and the continent as a whole. ${ }^{13}$ 
Insofar as the above statement alludes to China's mutual interest and co-operation in developing Africa's natural resource sector, it also illuminates the fact that this sector has become a potential area of investment for Chinese state-owned enterprises (SOEs) and its aspirant multinationals as part of the government's 'Going Global' strategy. Driven by the need to satisfy the demands of the expanding domestic

\section{Chinese investment in Africa}

Since 1996 China is a major investor in Sudan: 1) The state-owned China National Petroleum Corporation (CNPC) invests not only in oil exploration but also in production and transportation infrastructure in Sudan. Since 1996, CNPC has owned a 40\% stake in the Greater Nile Petroleum Operating Company; 2) Sinopec is currently constructing a $1500 \mathrm{~km}$ pipeline to Port Sudan; 3) In 2001, Harbin Power Engineering Company (HPE) constructed the Sudan Power Station with the help of a $\$ 110$ million loan from China Eximbank.

Since 1997 Chinese businessmen have invested \$24 million since 1997 in a textile mill in Zambia. In recent years, China has poured more than $\$ 300$ million into mines, manufacturing projects, construction companies and agriculture.

\begin{tabular}{|l|l|}
\hline Since 2003 & Chinese companies are prospecting in Algeria, Niger and Chad. \\
\hline Since 2004 & Chinese companies are prospecting in Tunisia and Mali. \\
\hline 2004 & $\begin{array}{l}\text { CNPC agrees to invest } \$ 1 \text { million in an oil and gas exploration } \\
\text { project in Mauritania. }\end{array}$ \\
\hline 2004 & $\begin{array}{l}\text { China Eximbank issues a R2 billion credit line to Angola to rebuild } \\
\text { infrastructure, helping Sinopec to get concessions for further oil } \\
\text { exploration. The loan is connected to the guaranteed delivery of } \\
10 \text { 000 barrels of oil per day. }\end{array}$ \\
\hline 2006 & $\begin{array}{l}\text { Sinopec signs a technical evaluation deal for three onshore } \\
\text { oilfields in Gabon for possible production-sharing contract. }\end{array}$ \\
\hline 2006 & $\begin{array}{l}\text { CNOOC signs a production-sharing contract in Equatorial Guinea. } \\
\text { CNOOC buys a } 45 \% \text { stake in a Nigerian oil and gas field for }\end{array}$ \\
\hline
\end{tabular}

Sources: Published news articles and Deutsche Bank, 'China's Commodity Hunger: Implications for Africa and Latin America', Deutsche Bank Research, 13 June 2006. 


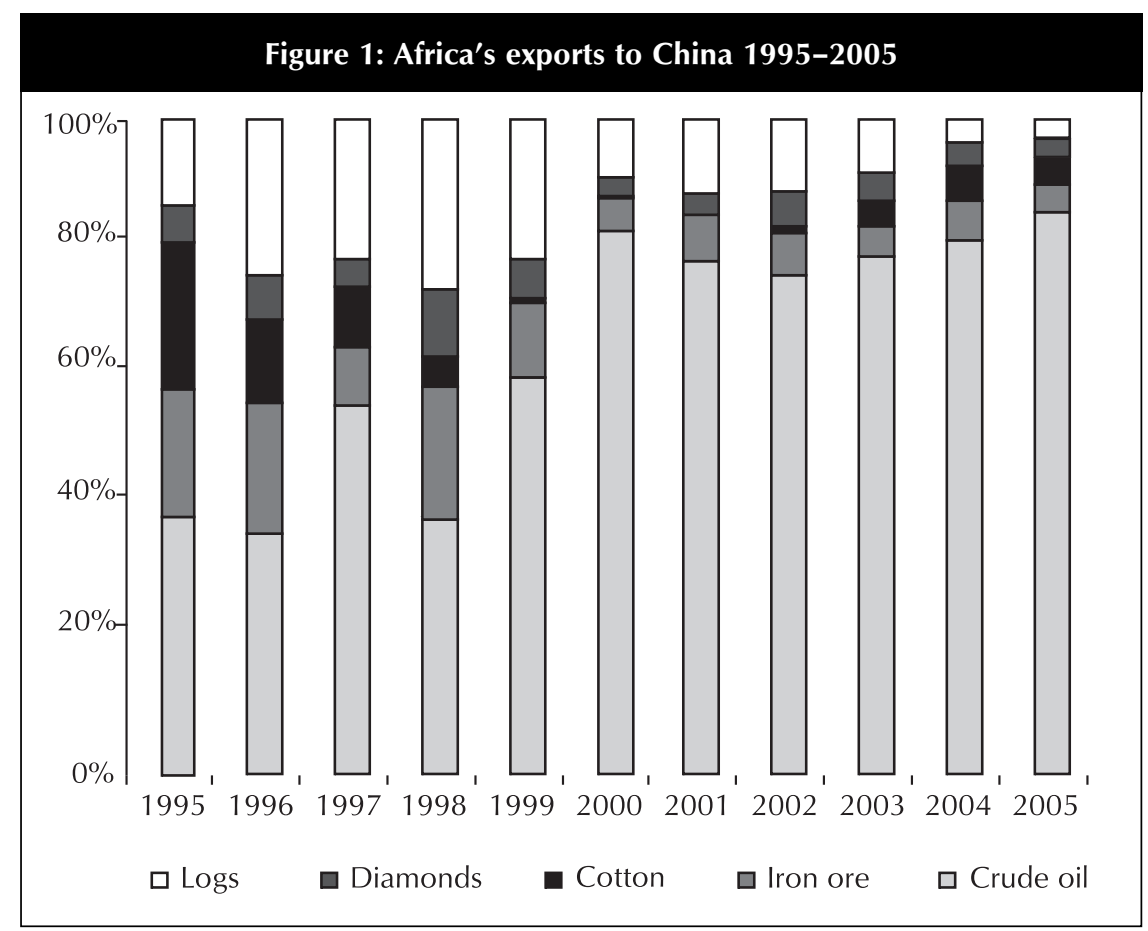

Source: World Atlas data in Tralac Data Analysis

economy, China is pursuing a 'dynamic, holistic approach to its energy partnerships in Africa'. ${ }^{14}$ As the box (opposite page) highlights, this strategy has paid dividends.

Clearly, China's commercial footprint on Africa is having a major impact on the natural resource sector, most notably in the energy industry. This is illustrated by Figure 1, which shows clearly that since 1995, crude oil has become the dominant import from Africa.

Even though the above data graphically captures the dominance of Africa's oil and mineral sector in China's engagement with the continent, it is the business opportunities that have emerged for its corporations that have entrenched Beijing's interest in Africa.

China's three largest national oil companies, China National Offshore Oil Corporation (CNOOC), China National Petroleum Corporation (CNPC) and China Petroleum and Chemical Corporation (Sinopec) $)^{15}$ have either acquired stakes in established African operations, or have entered into prospecting deals and exploration contracts with major oil producing countries. These include Nigeria, Angola, Sudan, Equatorial Guinea, Gabon and Chad. 
Figure 2: Presence of Chinese oil companies over a 10-year period

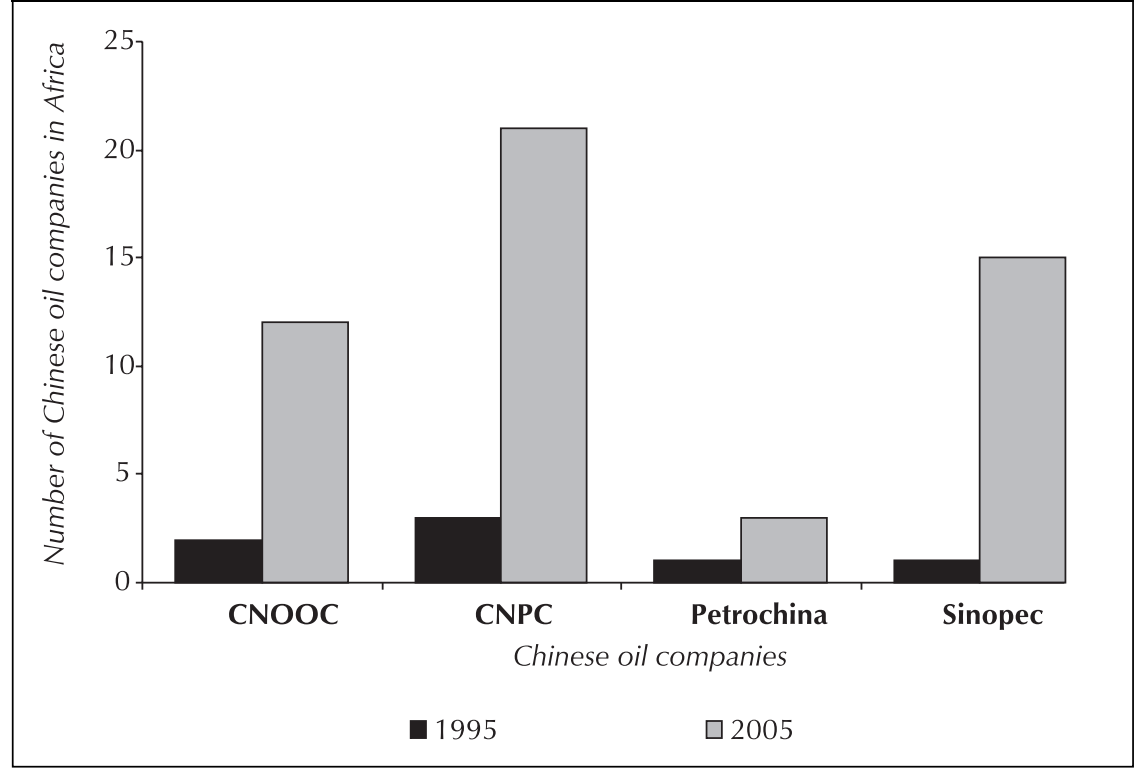

Source: Centre for Chinese Studies

This trend has been a relatively recent phenomenon. Whereas in 1995 these three corporations had virtually no presence in the African energy sectors, in a decade their presence has multiplied, as is captured in Figure 2.

To quantify the penetration of Africa's energy market by Chinese companies and put into perspective the speed with which these operations are being initiated, consider the following:

- In 2002, Sinopec signed a contract for $\$ 525$ million to develop the Zarzaitine oil field in Algeria. In 2003, CNPC purchased oil refineries in Algeria for $\$ 350$ million and signed an exploration deal for oil in two blocks, while PetroChina signed a contract with Algeria's Hydrogen Carbide to jointly develop oilfields and construct a refinery. ${ }^{16}$ In January 2005, China's Eximbank extended a $\$ 1$ billion oil-backed loan to Angola, which was later doubled and increased to $\$ 3$ billion in 2006 for the rebuilding and upgrading of infrastructure destroyed by the civil war. The latter enabled Sinopec to secure concessions for further oil exploration.

- In 2005, China and Nigeria signed an $\$ 800$ million crude oil deal 
to supply 30000 barrels of crude oil per day to China. ${ }^{17}$ In Côte d'Ivoire, Sinopec has purchased a $27 \%$ stake in an oil field off the coast. In 2006, an offshore exploration deal was signed with Kenya, allowing CNOOC to explore in six blocks covering 44500 sq miles in the north and south of the country. ${ }^{18}$

It was reported by the Daily Champion in Lagos in 2006 that Beijing had struck a $\$ 4$ billion deal for drilling licences in Nigeria while The Standard in Beijing announced that Angola's Sonangol said Sinopec had taken up a $40 \%$ stake in the lucrative oil Block 18 after paying a $\$ 1,1$ billion 'signature bonus' to the government out of a total investment of more than $\$ 1,4$ billion..$^{19}$ Moreover, Sinopec and Sonangol have entered into a joint venture partnership to build an oil refinery in Lobito.

Chinese companies have also signed contracts to begin offshore oil exploration and production in Congo-Brazzaville. ${ }^{20}$ They are also exploring for oil in northern Namibia and are considering establishing an oil refinery. ${ }^{21}$

- In 2006, the Zhongyuan Petroleum Company began exploratory drilling in the Gambella Basin in western Ethiopia ${ }^{22}$ while CNPC and Sinopec teamed up to exploit newly discovered drilling rights to an oilfield in Sudan in a deal worth about $\$ 600$ million. ${ }^{23}$ In 2006, Chinese companies also entered the Madagascar market via a joint venture with the country's national oil company to explore joint upstream ventures following the discovery of oil there. $^{24}$

The above examples demonstrate that China's energy interests are being well-served by the flurry of activity its corporations have undertaken, and supports the assertion made by China's state-owned media that the country's exploration and acquisition expeditions for new oil fields beyond its borders are akin to 'new silk roads'. ${ }^{25}$

\section{It's not just about oil}

China's interest in Africa is not only confined to energy markets; it also extends to the continent's mineral-rich countries. With copper, base metals, and wood being an integral part of China's economic boom, Chinese companies are taking advantage of investment opportunities in African markets. Reports suggest that at present between 700 and 800 Chinese companies, ranging from big corporations to small 
enterprises covering an array of industries, have invested on the continent.

In Zambia, the dormant Chambishi Copper Mine, which closed its doors in 1988, was resurrected by a Chinese company that brought in new investment and management. By 2006, the mine was producing 50000 tonnes of copper concentrates from 800000 tonnes of ore. As Princeton Lyman notes, China has invested nearly $\$ 170$ million in Zambia's mining sector as well as in other industries. ${ }^{26}$

Chinese interest in logging has made Mozambique's Zambezi province a principal exporting region for China. China is the biggest importer of timber globally and in 2005 Beijing imported 134 million cubic metres of timber valued at $\$ 16$ billion. This figure is certain to double over the next decade. ${ }^{27}$

Furthermore, Deutsche Bank notes that according to 2004 data, Gabon, the Republic of Congo, Equatorial Guinea and Cameroon accounted for $14 \%$ of China's rough wood imports. ${ }^{28}$ The report says South Africa, the continent's largest iron ore producer, is China's fourth largest supplier of iron ore; Gabon, South Africa and Ghana are among China's top five manganese suppliers and together account for $37 \%$ of China's total manganese imports while Africa is China's main supplier of cobalt, with $85 \%$ of imports coming from three countries: the Republic of Congo, the Democratic Republic of Congo and South Africa. ${ }^{29}$

According to a report by SouthScan in 2005, Chinese businessmen have been aggressively prospecting in the DRC. Following the visit by President Joseph Kabila to Beijing in March 2005, a delegation from COBEC, a Beijing-based company, have had discussions with the Mining Ministry regarding plans to rehabilitate the Kamatanda copper and cobalt mines as well as three copperprocessing plants in Katanga in a deal worth $\$ 27,5$ million. ${ }^{30}$

In April 2005, Feza Mining, a joint venture between the Chinese company Wambao Resources and the Congolese company Comide, opened a plant in Likasi with a production capacity of 4000 tonnes of cobalt-copper alloys, while Chinese expertise has been provided to equip the Congolese company with a 14600 tonne capacity furnace to process cobalt and copper ore. ${ }^{31}$ The UK-based NGO, Global Witness, noted that China was buying about $\$ 100$ million of Congolese cobalt a year. ${ }^{32}$

Apart from the cobalt and copper ore, China's interests in the DRC also extend to rich copper stones called heterogenite. According to a BBC report, independent operators in the country extract about $35 \%$ of the precious stones. These are sold mainly through middlemen 
to foreigners from, inter alia, China, which has furnaces in nearby towns in the DRC and Zambia where the gems are partly treated and thereafter exported, mostly to China via South African and Tanzanian ports. ${ }^{33}$

Even in Zimbabwe, which has been largely isolated by Western states, Beijing has shown keen interest in the country's platinum reserves and speculation is that deals are imminent in other areas such as coal, ferrochrome and steel. It is believed that China plans to invest more than $\$ 1$ billion in the country.

\section{Is Africa's Silk Road filled with potholes? ? $^{34}$}

In analysing the literature on and statements about China's engagement with Africa, it appears that it is fraught with contradictions. On the one hand, African producers have been marginalised and displaced from the market because of the influx of cheap Chinese goods. Yet as consumers these individuals have gained because of the affordability of Chinese products. But as China entrenches itself within the production of high-tech white goods, these very same consumers will again not be able to afford to purchase such goods. This will be because their livelihoods will have been eroded by competition from cheap Chinese goods.

Attempting to contextualise the push and pull factors that inform this engagement with Africa, especially from the perspective of the natural resource sector and in terms of the impact that this engagement may have on the continent's development trajectory, is complex.

Chris Alden argues that China's contemporary relations with Africa are driven by four factors. These are: resource security; the need for new markets and investment opportunities; symbolic diplomacy, development assistance and co-operation; and forging strategic partnerships. ${ }^{35}$ But this description of the drivers of China's engagement with the continent does not adequately explain the underlying strategic vision of the Chinese vis-à-vis Africa. Through the acquisition of key energy and commodity assets, China seeks to leverage its investments to extract itself from international commodity market pricing.

China's long-term strategy is to secure commodity assets at source, thus bypassing international market pricing. It may even consider establishing its own commodity exchanges - already having done so by setting up a diamond exchange in Shanghai to rival that in Antwerp. Thus the price that China pays for specific commodities will 
be negotiated at source with recipient governments rather than the price determined by the 'market'. This is the underlying factor of China's strategic engagement of African commodity and energy endowed economies.

The core of China's global foreign policy is resource security to enable the country to maintain its current high levels of growth. But the complexities around how these resources are extracted have become critical to China's image as a nation that prioritises respect for sovereignty at all costs. This is especially true in the African context.

With Africa's marginalisation from the global economy, the continent badly needs development. It is against this backdrop that the merits or shortcomings of China's engagement can be measured.

China's relationship with Africa is seen as a refreshing alternative to the traditional engagement models of the West. African governments and protagonists see China's engagement as a point of departure from Western neo-colonialism and political conditions. To this end they point to the sophisticated way China combines its need for resources with diplomacy to court African leaders. This is demonstrated in several interrelated ways. Firstly, China accords Africa an equal diplomatic status with the dominant powers in terms of its political engagement. China's leaders include African countries in the same itinerary as visits to either the United States or European Union, for example. Such political symbolism not only legitimises China in the eyes of African countries but it also paves the way for its strategic economic engagement.

China's commercial engagement with Africa is characterised by its 'coalition investment' strategy. Multiple Chinese state-owned companies across diverse industries are politically orchestrated to engage a recipient African economy in a way that can include tying energy acquisitions to funding for infrastructure development. In many resource-rich African countries, investments in road, rail, and ports have been a characteristic of Chinese energy projects. Angola is a primary example.

This highlights the third and most important point of all, namely the development assistance and co-operation that Beijing extends to African governments as part of its overall commercial engagement. This is channelled through concessional loans and other types of funding to projects such as the construction of hospitals, schools, sport stadiums, government buildings, debt forgiveness, academic training and technical training.

African economies are, however, quickly becoming overly dependent on commodity exports to the Chinese economy. The IMF 
recently reported in its World Economic Outlook Report that subSaharan Africa's growth rate could rise to $6.3 \%$ from the current $5 \%$ $5.5 \%$ range as a result of the rise in oil prices and the commodity boom. But if Africa is to better integrate itself into the global economy, it has to shift its current activities in the natural resource sector towards secondary and tertiary production.

\section{Conclusion}

China's foray into Africa's natural resource sector will continue to expand in the medium term. With China strategically excluded from the Middle East region for its energy needs, Africa is rapidly becoming China's commercial sphere of influence. The US invasion of Iraq may also have pushed the Chinese government to accelerate its acquisition of African energy assets.

As a result, China now obtains roughly a third of its energy imports from the African continent. Its mercantilist approach to business in Africa is being led primarily by its state-run corporations which, seemingly, are less cognisant of risk than their western counterparts. Chinese SOEs answerable to political stakeholders rather than private shareholders enjoy a comparative advantage over foreign multinationals when investing in African economies because of the strong, no-stringsattached political relations fostered by their government.

For recipient African economies, revenues from oil exports to China need to be utilised to invest in long-term industrial development strategies. Emboldened by resource nationalism, the danger is that these states will shy away from necessary political and economic reforms. On the back of China-derived revenue, the opportunity for economic diversification and sustainable development exists and may be embraced by Africa's developmental states but most likely to be wasted by its predatory regimes.

\section{Endnotes}

1 DR MARTYN DAVIES is Director of the Centre for Chinese Studies at Stellenbosch University, South Africa. He is also CEO of Emerging Market Focus and a Senior Lecturer at the Gordon Institute of Business Science. SANUSHA NAIDU is a Research Fellow at the Centre for Chinese Studies.

2 Pham PJ, 'China Goes on Safari', World Defense Review, 24 August 2006.

3 Trinh T \& S Voss, 'China's Commodity Hunger: Implications for Africa and Latin America', Deutsche Bank Report, 13 June 2006, p.1. 
4 Ibid.

5 Eisenman J \& J Kurlantzick, 'China's Africa Strategy', Current History, May 2006, pp.219-264.

6 Trinh \& Voss, op. cit., p.2.

7 Ibid.

$8 \mathrm{lbid}, \mathrm{p} .3$.

9 Copper is mainly used for electrical products such as wires and conductors in integrated circuits as well as in metal products like pipes, tubes and machine tools.

10 Pan E, 'China, Africa, and Oil', New York Times, 18 January 2006.

11 Wolfe A, 'The increasing importance of African Oil', The Power and Interest News Report, 20 March 2006, at http://www.pinr.com/report.php?ac=view_report\& report_id=460.

12 lbid.

13 People's Republic of China, China's Africa Policy, Beijing: PRC, 12 January 2006, at http://www.fmprc.gov.cn/eng/zxxx/t230615.htm/.

14 Fischer-Thompson J, 'China has sophisticated energy strategy for Africa, experts say', The Washington File, USI Department of State, Washington, 15 September 2006.

15 Ian Taylor, a senior lecturer in the School of International Relations at the University of St. Andrews in Scotland, highlights, in a recently published article entitled 'China's oil diplomacy in Africa', International Affairs, 82, 5, 2006, pp.937-959, notes the following about how the operations of the three national energy companies are structured. CNOOC operates offshore exploration and production. CNPC and Sinopec were established as vertically integrated oil and petrochemical corporations with interests that extended across the whole value chain. CNPC has been mostly involved in exploration of oil and gas fields, production and upstream activities and now accounts for $66 \%$ of both China's oil and gas output, and $42 \%$ of Beijing's refining capacity. Sinopec makes up $23 \%$ of oil output, $11 \%$ of gas output and $54 \%$ of refining capacity. For a more in-depth analysis of China's energy sector, and an overview of these three corporations see Nolan P \& J Zhang, The Challenge of Globalisation for Large Chinese Firms. Geneva: UNCTAD, 2002, p.21; Myers A \& S Lewis, 'Beijing's oil diplomacy', Survival, 44, 1, Spring 2002, pp.115134; Andrews-Speed P, Dow S \& Z Gao, 'The ongoing reforms to China's government and state sector: The case of the energy industry', Journal of Contemporary China, 9, 23, 2000.

16 Weizhong X, 'A Review of Sino-Algerian Relations in Retrospect', China.org.cn, 2 February 2004, quoted in Taylor, op. cit.

17 Nigeria to supply china 30,000 B/D of crude oil', Vanguard (Lagos), 12 July 2005, quoted in Taylor, 2006, op. cit.

18 'Kenya signs exploration contract', East African Standard (Nairobi), 18 April 2006, quoted in Taylor, 2006, op. cit.

19 'Nigeria-China relations', Daily Champion (Lagos), 5 May 2006; 'Oil deals likely as Angola turns east', The Standard (Beijing), 21 June 2006, quoted in Taylor, 2006, op. cit.

20 'Chinese premier visits oil-producing Congo', Associated Press (Brazzaville), 19 June 2006, quoted in Taylor, 2006, op. cit.

21 'Oil reserves in the pipeline', New Era (Windhoek), 12 April 2006, quoted in Taylor, 2006, op. cit.

22 'Chinese oil company starts drilling', The Reporter (Addis Abba), 4 March 2006.

23 'Sinopec, CNPC to acquire Sudan oil block for $\$ 600$ million', Associated Press (Hong 
Kong), 15 November 2006, quoted in Taylor, 2006, op. cit.

24 'CNPC, Madagascar Petroleum to explore Madagascar oil field', Dow Jones (Hong Kong), 24 February 2006.

25 Finch J, 'China's race for energy security - 2010', The Conservative Voice, at http://www.theconservativevoice.com/article/17213.html\#.

26 Lyman P, 'China's rising role in Africa', Presentation to the US-China Commission, Washington DC, 21 July 2005, at http://www.cfr.org/publication/8436/.

27 Christianson D, 'Unpacking Africa's great Asian opportunity', Business in Africa, May 2006.

28 Trinh \& Voss, op. cit., p.7.

29 Ibid.

30 'China scoops up minerals, infrastructure contracts', SouthScan, 3 June 2005.

31 lbid.

32 Ibid.

33 Zajtman A, 'Chinese demand boosts DR Congo mines', BBC News, 10 June 2006, at http:// http://news.bbc.co.uk/2/hi/business/4351019.stm.

34 The question was adapted from the article by Finch, op. cit.

35 Alden C, 'China in Africa', Survival, 47, 3, Autumn 2005. 